\title{
Ograniczenie prawa wiernego do Eucharystii - kan. 915 Kodeksu prawa kanonicznego z 1983 roku
}

Eucharystia, która stanowi centrum całego życia chrześcijańskiego, z jednej strony jest dla wiernego wielkim darem, ale z drugiej obliguje go do przestrzegania norm czuwających nad godziwym przystępowaniem do Najświętszego Sakramentu. Kanon 912 kodeksu Jana Pawła II, który uściśla normę 213 tegoż samego kodeksu, stanowi o tym, że każdy ochrzczony może i powinien zostać dopuszczony do Eucharystii, o ile tylko prawo mu tego nie zabrania. W związku z powyższym prawo do Komunii Świętej nie ma charakteru bezwzględnego. Ograniczenia prawne zawarte są w kan. 913, 915 oraz w kan. 844 obowiązującego prawodawstwa kościelnego ${ }^{1}$.

M. Kaiser, Wer darf zur heiligen Kommunion zugelassen werden? Zur Interpretation von c. 915 CIC mit besonderer Berücksichtigung der Frage, ob Wiederverheiratete Geschiedene davon betroffen sind, [w:] Iuri canonico promovendo, red. H. Schmitz, W. Aymans, Regensburg 1994, s. 175-206; zob. H. Pree, „Unio Irregularis”-Der Sakramentenempfang von Geschiedenen, geschiedenen Wiederverheiraten, ehelos Zusammenleben und nur zivil verehelichten Katholiken nach kanonischem Recht, [w:] Neue Positionen des Kirchenrechts, red. K. Lüdicke, H. Paarhammer, D. Binder, Graz 1994, s. 119-152. 
Zgodnie z kan. 915 Kodeksu prawa kanonicznego z 1983 roku² do Eucharystii nie należy dopuszczać tych, którzy są ekskomunikowani lub podlegają interdyktowi, po wymierzeniu bądź deklaracji kary, jak również innych osób trwających z uporem w jawnym grzechu ciężkim. Treść tego kanonu adresowana jest do szafarzy sakramentów, a w szczególności szafarzy Komunii Świętej, czyli tych, którzy decydują o dopuszczeniu do niej poszczególnego wiernego $^{3}$.

\section{Regulacje prawne przed Kodeksem prawa kanonicznego z 1983 roku}

Jedynym źródłem przytaczanym w przypisie źródłowego wydania Kodeksu prawa kanonicznego z 1983 roku do kan. 915 jest kan. 855 Kodeksu prawa kanonicznego z 1917 roku $^{4}$. Norma ta w sprawie dopuszczania do Eucharystii stanowiła, iż należy powstrzymać od niej tych, którzy są publicznie niegodni, tzn. ekskomunikowani, podlegają interdyktowi oraz w sposób jawny są zniesławieni, chyba że stwierdzono ich pokutę i poprawę oraz zadośćuczynili wcześniej publicznemu zgorszeniu. Szafarz mógł odmówić udzielenia sakramentu również grzesznikowi tajnemu, jeśli nie stwierdził jego poprawy; nie mógł tego natomiast uczynić, gdy prosił publicznie i nie można go było pominąć bez zgorszenia ${ }^{5}$. Tekst ten zawarty był już w Rytuale rzymskim z 1614 roku, który do osób zniesławionych zaliczał przykładowo: nierządnice, konkubinariuszy, lichwiarzy, wróżbitów, wieszczów i bluźnierców ${ }^{6}$.

2 „Do Komunii świętej nie należy dopuszczać ekskomunikowanych lub podlegających interdyktowi, po wymierzeniu lub deklaracji kary, jak również innych osób trwających z uporem w jawnym grzechu ciężkim" (kan. 915 KPK).

3 Zob. F. R. Aznar Gil, J. R. Flecha Andrés, Divorciados y Eucaristia, Salamanca 1996.

4 Codex Iuris Canonici, fontium adnotatione et indice analytico-alphabetico auctus, Pontificia Commissio Codici luris Canonici Authentice Interpretando, Libreria Editrice Vaticana 1989, can. 915.

5 Kan. $855 \$ 1$ KPK 1917: „Arcendi sunt ab Eucharistia publice indigni, quales sunt excommunicati, interdicti manifestique infames, nisi de eorum poenitentia et emendatione constet et publico scandalo prius satisfecerint”; $\$ 2$ : „Occultos vero peccatores, si occulte petant et eos non emendatos agnoverit, minister repellat; non autem, si publice petant et sine scandalo ipsos praeterire nequeat".

6 Rituale Romunum Pauli V Pontificis Maximi iussu editum, atque a fel. Recordat. Benedicto XIV, auctum \& castigatum, editio novissima, Bassani 1773, s. 52, nr 8: „Fideles omnes 
Prace nad reformą kodeksu po Soborze Watykańskim II przyniosły pewne zmiany. Do schematu prawa o sakramentach z roku 1975 wprowadzono nową formułę, która stanowiła, iż do celebracji Eucharystii albo do Komunii Świętej nie należy dopuszczać tych, którzy trwają w jawnym grzechu ciężkim ${ }^{7}$. W schemacie z 1980 roku w kan. 867 zapisano natomiast, że do Komunii Świętej nie należy dopuszczać tych, którzy zgrzeszyli ciężko i publicznie oraz w sposób jawny trwają w uporze ${ }^{8}$. W dyskusji nad schematem w 1981 roku niektórzy z konsultorów proponowali, aby w tym miejscu znalazł się tekst przewidujący możliwość dopuszczania do Komunii Świętej osób rozwiedzionych żyjących w ponownych związkach. Propozycji tej jednak nie przyjęto, ponieważ wszyscy zgodzili się, iż kompetentna do rozstrzygnięcia tej kwestii nie jest Komisja tylko Stolica Apostolska9. Ostatecznie zgodzono się na taką treść kanonu, ponieważ w normie tej zawarto wszystkie istotne elementy, tj. powagę czynu, jego jawność i upór grzesznika. $\mathrm{Z}$ całą pewnością tekst dotyczył także rozwiedzionych oraz pozostających

ad sacram Communionem admittendi sunt, exceptis iis, qui iusta ratione prohibentur. Arcendi autem sunt publice indigni, quales sunt excommunicati, inter dicti, manifestique infames: ut meretrices, concubinarii, foeneratores, magi, sortilegi, blasphemi, $\&$ alii eius generis publici peccatores; nisi de eorum poenitentia $\&$ emendatione constet $\&$ publico scandalo prius satisfecerint”; nr 9: „Ocultos vero peccatores si oculte petant, \& non eos emendatos agnoverit, repellat; non autem si publice petant, $\&$ sine scandalo ipsos praeterire nequeat". Zob. J. Hendriks, Ad sacram communionem ne admittantur... Adnotationes in can. 915, „Periodica de re morali, canonici, liturgica”, R. 79, 1990, s. 166; por. F. Bączkowicz, Prawo kanoniczne. Podręcznik dla duchowieństwa, t. 2, Opole 1957, s. 38.

7 Pontificia Commissio Codici Iuris Canonici Recognoscendo, Schema Documenti Pontificii quo Disciplina Canonica de Sacramentis Recognoscitur, Typis Polyglottis Vaticanis 1975, kan. 75: „Ad Sanctissimae Eucharistiae celebrationem aut communionem ne admittantur qui graviter deliquerunt et in contumacia manifesto perseverant".

8 Pontifica Commissio Codici Iuris Canonici Recognoscendo, Schema Codicis Iuris Canonici iuxta animadversiones S. R. E. Cardinulium, Episcoporum Conferentiarum, Dicasteriorum Curiae Romanae, Universitatum Facultatumque ecclesiasticarum necnon Superiorum Institutorum Vitae Consecratae recognitum, Libreria Editrice Vaticana 1980, kan. 867: „Ad sacram communionem ne admittantur qui graviter et publice delique runt et in contumacia manifesto perseverant".

9 "Nonnulli in animadversionibus petierunt ut hoc in loco textus exhibeatur qui praevideat possibilitatem adeundi ad sacram communionem pro fidelibus divortititis et denuo coniugatis. Omnes Consultores concordant Commissionis non esse de istis decernere; erit Sanctae Sedis ąuaestioni respondere” („Communicationes”, 1981, vol. 13, s. 412). 
w ponownych związkach małżeńskich ${ }^{10}$. Powodem natomiast zmiany treści kanonu - jak się wydaje - nie było odnowienie w tej sprawie dyscypliny Kościoła czy wprowadzenie nowej, lecz trafniejsze wyrażenie obowiązującej nauki o obyczajach z uwzględnieniem wyjaśnień Magisterium Kościoła, moralistów i kanonistów ${ }^{11}$. Co do osób publicznie niegodnych, to kan. 855 $\$ 1$ KPK 1917 dopuszczał - zdaniem niektórych autorów - pewien wyjątek. $\mathrm{Na}$ przykład z obawy przed bardzo poważną szkodą wolno było udzielić sakramentu komuś, kto zgodnie z zasadami kanonu nie powinien był zostać dopuszczony ${ }^{12}$. Spełnienie tych warunków, o których mowa w kanonie, występowało w wystarczający sposób, gdy można było domniemywać, że dana osoba odbyła spowiedź ze względu na zmianę zewnętrznego trybu życia, jakim było na przykład zerwanie konkubinatu. Jeden z kanonistów Hendriks uważa, że wyrażenie arcendi sunt w tekście prawnym jest mniej trafne, ponieważ zgodnie z ogólnymi zasadami moralnymi współdziałanie materialne jest niekiedy szafarzowi dozwolone. Nowa formuła: „ad sacram communionem ne admittantur” wydaje się lepsza, gdyż nie zezwala na współdziałanie formalne świadczone osobie niegodnej Komunii Świętej, nawet jeśli nie zawsze wyklucza współdziałanie materialne. Nie należy więc dopuszczać tych, którzy - być może - w innych przypadkach z proporcjonalnie ważnych powodów nie powinni zostać odsunięci, ale winni być tolerowani. W kan. $855 \$ 2$ kodeksu pio-benedyktyńskiego pozostawiono regulację dotyczącą grzeszników tajnych, którym należało udzielić sakramentu Eucharystii, jeśli prosili

Io „Textus sufficit cum omnia requisita habeat: actus gravitas, nempe, et publicitas actus necnon contumacia. Certo ceritus textus respiciat etiam divortiatos et renuptiatos” („Communicationes”, 1983, vol. 15, s. 194).

II J. Hendriks, Ad sacram communionem, dz. cyt., s. 166; W czasach obowiązywania kodeksu pio-benedyktyńskiego niektórzy twierdzili, iż udzielanie sakramentu niegodnemu nie jest działaniem wewnętrznie złym i dlatego taką praktykę można czasami tolerować, a nawet zalecać. Udzielanie Komunii Świętej osobie niegodnej można nazwać współdziałaniem materialnym na rzecz grzechu drugiej osoby, a jest ono dozwolone, ilekroć istnieją proporcjonalnie poważne powody i dobra intencja szafarza. Wynikało to również z $\$ 2$ kan. 855 KPK 1917, zgodnie z którym nie należało od Komunii Świętej odsuwać grzeszników tajnych, jeżeli publicznie prosili o sakrament i nie można ich było pominąć bez zgorszenia.

${ }_{12}$ Taka interpretacja opierała się na przykładzie dopuszczenia do Komunii Świętej Judasza Iskarioty w czasie Ostatniej Wieczerzy. Zob. STh III q. 81, a. 2. 
o to publicznie i nie można ich było pominąć bez zgorszenia ${ }^{13}$. Wyjaśnienie tego kanonu, zdaniem Hendriksa, było jedną z kwestii omawianych w podręcznikach teologii moralnej - zresztą nie zawsze w sposób przekonujący ${ }^{14}$.

Zgodnie z unormowaniami Kodeksu prawa kanonicznego z 1917 roku nie należało do Komunii Świętej dopuszczać publicznie niegodnych, zaliczając do nich ekskomunikowanych, podlegających interdyktowi i w sposób jawny zniesławionych. Grzesznik był publicznie niegodny (jawnie zniesławiony), kiedy jego przestępstwo zostało rozgłoszone lub z łatwością mogło takim się $\operatorname{stac}^{15}$. Z tego względu grzesznicy ci w miejscach, gdzie ich stan moralny był nieznany, mogli przystępować do sakramentów.

\section{Kan. 915 kodeksu Jana Pawła II}

W nowym sformułowaniu kanonu, kto nie został ekskomunikowany lub obciążony interdyktem po wymierzeniu lub deklaracji kary i nie trwa z uporem w jawnym grzechu ciężkim, a został ochrzczony w Kościele katolickim ${ }^{16}$ lub dopuszczony do sakramentów na podstawie kan. 844 KPK

I3 Według F. Bączkowicza narażona na zdradę zostałaby tajemnica spowiedzi. Por. F. Bączkowicz, Prawo kanoniczne, dz. cyt., t. 2, s. 38.

I4 Por. J. Hendriks, Ad sacram communionem, dz. cyt., s. 169.

is Według KPK 1917, kan. 2197: „Delictum est: 1. Publicum, si iam divulgatum est aut talibus contigit seu versatur in adiunctis ut prudenter iudicari possit et debeat facile divulgatum iri; 2 . Notorium notorietate iuris, post sententiam iudicis competentis quae in rem iudicatam transierit aut post confessionem delinquentis in iudicio factam ad normam can. $1750 ; 3$. Notorium notorietate facti, si publice notum sit et in talibus adiunctis commisum, ut nulla tergiversatione celari nulloque iuris suffragio excusari possit”. Za grzeszników publicznych należy uważać tych, których ciężkie grzechy są już powszechnie znane, albo poprzez wyrok sędziego, albo poprzez ewidentny występek popełniony w miejscu publicznym, albo też podany do wiadomości wielu osób poprzez plotkę. Nie stanowi przeszkody fakt, że przestępstwo jest nieznane kilku osobom wśród obecnych. Bardziej słuszne jest natomiast nieodmawianie sakramentu grzesznikowi proszącemu publicznie, którego grzech nie jest jeszcze powszechnie znany. Zawsze wyłączyć należy przypadki, w których szafarz powinien roztropnie obawiać się, aby poprzez udzielanie sakramentu nie powstało poważne zgorszenie wiernych, np. jeśli przewiduje się, że do danego miejsca wiadomość o przestępstwie dotrze w krótkim czasie. Zob. E. Genicot, Institutiones Theologiae Moralis, septima post CIC quam recognovit I. Salsmans, S.I., Bruxellis 1939, editio 14, vol. 2, s. 108, nr 122.

16 Zob. kan. $842 \$ 1$, kan. 912 KPK 1983. 
1983 i przyjął już pierwszą Komunię Świętą ${ }^{17}$, powinien zostać dopuszczony do Eucharystii. W normie tej nie ma mowy o publiczności grzechu ${ }^{18}$.

Kto zatem podlega normie tego kanonu, poza ekskomunikowanymi i podlegającymi interdyktowi po wymierzeniu lub deklaracji kary? Kanon mówi o tych, którzy trwają z uporem w jawnym grzechu ciężkim. Upór występuje wtedy, gdy ktoś zdecydowanie nie chce zmienić swojego sposobu życia. Jawność grzechu wówczas, kiedy jest on pewny, określony, przynajmniej sam w sobie publiczny i kiedy jest on znany konkretnej wspólnocie eucharystycznej ${ }^{19}$. Prawodawca używa słów „grzech ciężki”, nie wymaga natomiast od szafarza, by ten wydał osąd co do ciężkości materii grzesznego aktu. Grzech zatem - o którym mowa w kan. 915 - powinien być aktem obiektywnie złym i ciężkim, ponieważ nie powinno się nigdy stwierdzać, że grzech jest ciężki, jeżeli nie ma co do tego pewności. Grzech ten jest grzechem materialnym, ponieważ chodzi o grzech, który ze względu na przedmiot jest ciężki. Jeżeli akt pod względem przedmiotu nie jest ciężki albo zachodzi nieznaczne naruszenie materii, czy też istnieje tylko domniemanie, to wówczas nie można stwierdzić, że ktoś jest w ciężkim grzechu materialnym. Nie zawsze jest łatwo określić, czy chodzi o ciężki grzech materialny, czy $n^{2} e^{20}$. Magisterium Kościoła w poszczególnych przypadkach wyraźnie określa swoje stanowisko oraz interpretację norm ${ }^{21}$. Z całą pewnością do osób pozostających w jawnym grzechu ciężkim należą ci, którzy żyją w związkach nie-

${ }_{17}$ Zob. kan. 914 KPK 1983.

I8 Zob. E. Górecki, Najświętsza Eucharystia. Sprawowanie Eucharystii, [w:] Komentarz do Kodeksu Prawa Kanonicznego, red. J. Krukowski, t. 3/2, Poznań 2011, s. 100-101.

I9 Por. K. Lüdicke, Münsterischer Kommentar zum Codex Iuris Canonici, Essen 1985-, kan. 915/4: „Offenkundig ist eine Sünde dann, wenn sie der konkreten Eucharistiegemeinschaft bekannt ist oder ein mit ihr lebender Teilnehmer sie kennen müsste"; H. Schmitz, Taufe, Firmung, Eucharistie. Die Sakramente der Initiation und Ihre Rechtsfolgen in der Sicht des CIC von 1983, „Archiv für Katholisches Kirchenrecht”, R. 152, 1983, s. 400-401.

20 Ioannes Paulus PP. II, Adhortatio Apostolica Reconciliatio et poenitientia, nr 17, AAS, R. 77, 1985, s. 185-275: „De hac re Ecclesia habet suam doctrinam, quam quoad praecipuas eius partes confirmat, quamquam scit haud semper facile esse, in definitis condicionibus, certos ei constituere fines".

${ }_{21}$ Por. Ioannes Paulus PP. II, Motu proprio Iusti iudicis, 28 VI 1988, art. $6 \$ 1$, pkt 2: AAS, R. 80, 1988, s. 1258-1261: „qui in concubinatu vivunt aut matrimonio dviii tantum iuncti sunt vel aliter manifesto in gravi pecato perseverant”. 
sakramentalnych (w tzw. unio irregularis) oraz należący do masonerii i partii komunistycznych ${ }^{22}$.

\section{Wierny pozostający $\mathrm{w}$ unio irregularis}

\subsection{Pojęcie unio irregularis}

Jedyną właściwą i prawidłową formą tworzenia wspólnoty życia przez mężczyznę i kobietę jest sakramentalny związek małżeński. Każda inna forma, w której osoby pozostają ze sobą na sposób małżeński, ale małżeństwem nie są, uważana jest za nieprawidłową. Problem osób pozostających w takich związkach, po zakończeniu Soboru Watykańskiego II, był przedmiotem obrad synodów diecezjalnych oraz polemik naukowych ${ }^{23}$. Zagadnienie to stało się także przedmiotem obrad Synodu Biskupów, który odbył się w Rzymie w dniach od 26 września do 25 października 1980 roku, i obradował na temat zadań rodziny chrześcijańskiej we współczesnym świecie. W adhortacji posynodalnej Familiaris consortio, ogłoszonej 22 listopada 1981 roku, przedstawiona i przypomniana została nauka Kościoła odnośnie do rodziny, jej zadań i osób pozostających w nieprawidłowych jej formach ${ }^{24}$. Adhortacja wymienia cztery grupy takich związków, w których obecność strony katolickiej traktowana jest jako związek nieprawidłowy, a fakt ten określany jest jako unio irregularis ${ }^{25}$ :

22 Normie tego kanonu podlegają także ci, którzy w sposób jawny utrzymują się z aborcji.

23 Problemem tym zajmowały się synody pastoralne w Niemczech, m.in. Synod Pastoralny odbyty w latach 1971-1975 w Würzburgu, którego specjalna komisja wystosowała do papieża zapytanie, czy wierni rozwiedzieni mogą ponownie zawrzeć małżeństwo w Kościele katolickim, odnosząc się do klauzuli Mateuszowej (Mt 5, 32; 19, 9) oraz przywileju Pawłowego (1 Kor 7, 2-16), a także przez wzgląd na praktykę Kościoła wschodniego. Zob. P. Hünermann, Sakramente für wiederverheiratete Geschiedene - seit 25 Jahren umstritten, "Theologische Quartalschrift”, R. 175, 1995, s. 81-83; H. Müller, Barmherzigkeit in der Rechtsordnung der Kirche? „Archiv für Katholisches Kirchenrecht”, R. 159, 1990, s. 353-367.

24 Ioannes Paulus PP. II, Adhortatio Apostolica Familiaris consortio, AAS, R. 74, 1982, s. 81-191 [dalej: FC].

${ }_{25}$ Pojęcie unio dotyczy relacji zachodzących pomiędzy dwiema osobami bądź związkiem osób, stąd określenie unio irregularis wskazuje na „związek nieprawidłowy”, który należy odróżnić od „sytuacji nieprawidłowej”, i jest pojęciem szerszym; zob. M. Zalba, Num in unione irregutari degentes a sacramentis in iure arceanur, „Periodica de re morali, canoni- 
- do pierwszej należą osoby, które po rozwodzie cywilnym, przy trwaniu ich małżeństwa sakramentalnego, związały się ponownie w formie cywilnej, czyli rozwiedzieni żyjący w ponownych związkach małżeńskich ${ }^{26}$;

- do drugiej należą osoby, które bez zawarcia małżeństwa, czy to ze względu na przeszkodę węzła małżeńskiego, czy też jej braku, pozostają w faktycznej wspólnocie; osoby żyjące razem bez żadnej uznanej publicznie więzi instytucjonalnej, ani cywilnej, ani religijnej, czyli w rzeczywistych wolnych związkach oraz w tzw. małżeństwach na próbę ${ }^{27}$;

- do trzeciej należą katolicy związani tylko ślubem cywilnym, czy to ze względów ideologicznych, czy praktycznych ${ }^{28}$.

- do czwartej należą osoby, które po ważnie zawartym związku małżeńskim w Kościele katolickim rozwiodły się cywilnie i nie zawarły ponownie związku małżeńskiego (w tym przypadku bardziej adekwatne zdaje się właśnie określenie „sytuacja nieprawidłowa” niż związek nieprawidłowy) ${ }^{29}$.

Pozostawanie katolika w tego rodzaju związkach budziło zawsze wiele troski ze strony Kościoła i wymagało zajęcia odpowiedniego stanowiska. W posynodalnej adhortacji apostolskiej Familiaris consortio czytamy:

ca, liturgica", 1980, t. 69, s. 604-622; H. Pree, Unio Irregularis. Der Sakramentenempfang von Geschiedenen, geschiedenen Wiederverheirateten, ehelos Zusammenlebenden und nur zivil verehelichten Katholiken nach kanonischem Recht, „Anzeige für die Seelsorge”, 1994, z. 4, s. $145-157$.

26 FC 84.

${ }_{27}$ FC 80, 81. Tym bardziej należą do nich związki homoseksualne; zob. Kongregacja Doktryny Wiary, List do Biskupów Kościoła katolickiego o duszpasterstwie osób homoseksualnych Homosexualitatis problem, 1 X 1986, [w:] W trosce o petnie wiary. Dokumenty Kongregacji Doktryny Wiary 1966-1994, Tarnów 1995, s. 288-296; tekst oryginalny: AAS, R. 79, 1987, s. 543-554; por. także: Kongregacja Doktryny Wiary, Deklaracja o niektórych zagadnieniach etyki seksualnej Persona humana, 29 XII 1975, [w:] W trosce o petnie wiary, dz. cyt., s. 94-106; tekst oryginalny: AAS, R. 68, 1976, s. 77-96; zob. także: KKK 2357-2359, 2396. Do tej grupy osób należą również ci, którzy pozostają w związkach poligamicznych, kazirodczych, zajmują się prostytucją, sutenerstwem czy nierządem; por. KKK 2355, 2387-2388. Odrębny problem stanowi sytuacja duchownych i zakonników pozostających w związkach nieregularnych; zob. H. Pree, Priester ohne Amt. Probleme um die Amissio Status clericalis und ihre kirchenrechtlichen Rechtsfolgen, [w:] Scientia Canonum. Festgabe fur Franz Pototschnig zum 65. Geburtstag, red. H. Paarhammer, A. Rinnerthaler, München 1991, s. 233-273.
28 FC 82.
29 FC 83. 
Rodzina w dzisiejszych czasach znajduje się pod wpływem rozległych i szybkich przemian społecznych i kulturowych, wiele rodzin przeżywa ten stan rzeczy, dochowując wierności tym wartościom, które stanowią jej fundament, inne stanęły niepewne i zagubione wobec swych zadań, a nawet niekiedy zwątpiły i niemal zatraciły świadomość ostatecznego znaczenia i prawdy życia małżeńskiego i rodzinnego ${ }^{30}$.

Dlatego też Kościół określił sytuacje i warunki dopuszczania tych osób do sakramentów, szczególnie sakramentu pokuty i Eucharystii. W prawie sakramentalnym stawiane są pytania o prawo wiernego do sakramentów, o obowiązek szafarzy dotyczący ich udzielenia czy o prawo odmowy ${ }^{31}$, jak również pytanie o interpretację kan. 916, tj. osobistą decyzję przystąpienia do Komunii Świętej na podstawie własnego osądu sumienia ${ }^{32}$.

\subsection{Możliwość dopuszczenia do sakramentów}

Katolicy mają prawo otrzymywać od swoich pasterzy z duchowych dóbr Kościoła określone pomoce, zwłaszcza słowo Boże i sakramenty ${ }^{33}$. Te podstawowe prawa wiernych mają pewne granice ustanowione przez porządek prawny. Kanon 18 określa interpretację ustaw, które m.in. ograniczają swobodne wykonywanie uprawnień, mówiąc, iż podlegają one ścisłej interpretacji. Według kanonu 912 każdy ochrzczony, jeśli tylko prawo mu nie zabrania, może i powinien być dopuszczony do Komunii Świętej. Jest to więc ograniczenie prawa wiernego i dlatego podlega ścisłej interpretacji ${ }^{34}$.

Osoby rozwiedzione, które zawarły ponowny związek małżeński, nie moga przystępować do Eucharystii. Papież Jan Paweł II w adhortacji Familiaris consortio przypomina, że Kościół podtrzymuje swoją dotychczasową praktykę

30 FC 1.

31 Kan. 213, $843 \$ 1,912,915,980,1007$ KPK 1983.

32 Por. G. May, Das Verhältnis von Gesetz und Gewissen im kanonischen Recht, dargestellt an den cc. 915/916 CIC 1983, „Forum Katholische Theologie”, 1993, t. 9, s. 117-130; zob. J. Cleve, Die Interpretation von c. 915 CIC im Kontext der fundamentalen Pflichten und Rechte aller Gläubigen, [w:] Theologia et lus Canonicum. Festgabe fur Heribert Heinemann zur Vollendung seines 70. Lebensjahres, red. H. J. F. Reinhardt, Essen 1995, s. 385-396.

33 Kan. 213 KPK 1983.

34 Por. W. Aymans, K. Mörsdorf, Kanonisches Recht. Sakramenten der tätigen Ordnung, Eucharistie, Paderborn-München-Wien-Zürich 2007, s. 267-270. 
opartą na Piśmie św. i nie dopuszcza tych katolików do Komunii eucharystycznej ${ }^{35}$. Nie mogą być oni dopuszczeni do Komunii Świętej od chwili, gdy ich stan i sposób życia obiektywnie zaprzeczają tej więzi miłości między Chrystusem i Kościołem, którą wyraża i urzeczywistnia Eucharystia. Dopuszczenie ich do Eucharystii wprowadzałoby wiernych w błąd lub powodowałoby zamęt co do nauki Kościoła o nierozerwalności małżeństwa ${ }^{36}$.

To stanowisko Kościoła wywołuje duże kontrowersje i spory wśród tych, którzy starają się przyznać rozwiedzionym i ponownie związanym małżeństwem prawo przystępowania do sakramentów świętych. Na przykład biskupi niemieccy - O. Saier, K. Lehmann oraz W. Kasper 10 lipca 1993 roku wydali list pasterski w trosce o ludzi rozwiedzionych i ponownie związanych małżeństwem. Odwołując się do trudnej sytuacji współczesnego świata, rosnącej liczby rozwodów oraz Soboru Watykańskiego II, który w konstytucji Gaudium et spes stwierdził, iż: „Radość i nadzieja, smutek i trwoga ludzi współczesnych [...] są też radością i nadzieją, smutkiem i trwogą uczniów Chrystusowych” (nr 1), odnieśli się do zagadnienia możliwości rozłączenia małżonków. Biskupi uważają, że zarówno „klauzula Mateuszowa”, jak i „przywilej Pawłowy” dają taką możliwość rozłączenia, a Kościół nie może odwrócić się od tych grzeszników, ale właściwie ma szukać tych, którzy

35 FC 84. Na temat problemów dotyczących duszpasterstwa osób rozwiedzionych zob. m.in.: Congregatio pro Doctrina Fidei, Epistula Annus internationalis Familiae, 14 IX 1994, AAS, R. 86, 1994, s. 974-979; zob. W. Miziołek, Duszpasterstwo matżeństw niesakramentalnych, „Homo Dei”, 1981, nr 2, s. 117-129; tenże, Duszpasterstwo matżeństw niesakramentalnych, [w:] Ewangelizacja wspólnoty matżeńskiej i rodzinnej. Program duszpasterski na rok 1993/94, Komisja Episkopatu Polski Duszpasterstwa Ogólnego, Katowice 1993, s. 521-540; J. Salij, Kościot a matżeństwa rozwiedzionych, „W Drodze”, 1973, nr 2, s. 67-77; tenże, Dlaczego nie wolno mi przystępować do sakramentów?, „W Drodze”, 1985, nr 11-12, s. 188-192; M. Paciuszkiewicz, Jesteście w Kościele, Warszawa 1993; P. Góralczyk, Powtórne związki matżenskie w teologicznym i etycznym świetle, Ząbki 1995. Wiernych rozwiedzionych i żyjących w ponownych związkach należy otaczać troską duszpasterską i mimo że nie mogą przystępować do sakramentów, to należy im pomagać w głębszym zrozumieniu znaczenia pobożności eucharystycznej, wyrażającej się w takich praktykach, jak nawiedzanie Najświętszego Sakramentu, komunii duchowej, adoracji eucharystycznej; por. Zalecenia XIII Zgromadzenia Plenarnego Papieskiej Rady do Spraw Rodziny, Duszpasterstwo osób rozwiedzionych żyjących w nowych związach, 22-25 I 1997, „L'Osservatore Romano" (wyd. pol.), R. 18, 1997, nr 6, s. 50-52.

36 FC 84; por. Congregatio pro Doctrina Fidei, Epistula Annus internationalis Familiae, dz. cyt., s. 974-979, nr 4. 
„zaginęli”. Biskupi odnieśli się również do kwestii zobowiązania małżonków do życia jak brat z siostrą. Uważają, że taka forma jest dla wielu nienaturalna i niemożliwa, gdyż proponuje się małżonkom drogę heroicznego wyrzeczenia i ofiary, do której nie są przygotowani, ani takiego charyzmatu nie odczytali w swoim życiu. Zaproponowanie wszystkim takiej drogi wykracza poza ludzkie siły. Biskupi przedstawiają również propozycje dla duszpasterzy, którzy mieliby decydować o dopuszczaniu do sakramentów tych małżonków, którzy w swoim sumieniu przekonani są, że ich pierwsze małżeństwo nigdy nie było ważne, czy też po dłuższej pokucie i cierpieniu nabierają przeświadczenia, że Pan Bóg w swoim miłosierdziu przebaczył im już popełnione grzechy ${ }^{37}$.

Nauka i praktyka Kościoła w sprawie dopuszczania osób rozwiedzionych do sakramentów jest jednoznaczna i niezmienna. Nie mogą być oni dopuszczeni do Eucharystii, ponieważ żyją w grzechu cudzołóstwa (zob. 1 Kor 11,27$)^{38}$. Dla wiernych, którzy pozostają w takiej sytuacji małżeńskiej,

37 Zob. Die Bischofe der Oberrheinischen Kirchenprovinz, Zur seelsorglichen Begleitung von Menschen aus zerbrochenen Ehen, Geschiedenen und Wiederverheirateten Geschiedenen. Einführung, Hirtenwort und Grundsatze, Freiburg im Br--Mainz, Rottenburg-Stuttgart 1993, s. 27-31; zob. także: P. Góralczyk, Powtórne związki matżeńskie, dz. cyt., s. 212-220. Należy również przypomnieć, iż co do pogrzebu kościelnego tych wiernych, którzy w chwili śmierci znajdują się w sytuacji nieuregulowanego związku, dyscyplina kościelna uległa w stosunku do KPK 1917 złagodzeniu już w 1973 roku. Uchylono wówczas kan. 1240 KPK 1917; zob. List Kongregacji Doktryny Wiary, 29 V 1973 r., o pogrzebie kościelnym Cum plures Conferentiae, [w:] W trosce o petnię wiary, dz. cyt., s. 53; por. także kan. 1184 $\$ 1,3^{\circ} \mathrm{KPK} 1983$.

${ }^{3}$ KKK 2380, 2381. Kościół jednoznacznie podkreśla, że grzech cudzołóstwa jest grzechem śmiertelnym. W doktrynie jednak istnieją poglądy, że nie każde małżeństwo niesakramentalne pozostaje w grzechu ciężkim; zob. P. Góralczyk, Powtórne związki matżeńskie, dz. cyt., s. 180-181. Szerzej na temat tego zagadnienia w literaturze por. W. Góralski, Problem dostępu do sakramentów osób żyjących w matżenstwach pozasakramentalnych, [w:] Matżeństwo i rodzina w świetle nauki Kościoła i wspótczesnej teologii, red. A. L. Szafrański, Lublin 1985, s. 323-343, 329; P. Huizing, Nierozerwalność matżeństwa w prawie kanonicznym, „Concilium”, 1968, nr 1-10, s. 423-431 [dalej: Conc]; B. Haring, Piecza nad zbawieniem rozwiedzionych i nieważnie poślubionych, Conc, 1970, nr 1-5, s. 361-363; P. Hoffmann, Stowa Jezusa o rozwodzie $i$ ich interpretacja w przekazie nowotestamentowym, Conc, 1970, nr 1-5, s. 330-340; M. Kaiser, Warum dtirfen wiederverheiratete Geschiedene (nicht) zu den Sakramenten zugelassen werden?, „Stimmen der Zeit”, 1993, nr 211, s. 741-751; M. Theobalt, Jesu Wort von der Ehescheidung, "Theologische Quartalschrift”, 1995, nr 175, s. 109-124; B. J. Hilberath, Sakramentalitat und Unauflosliclikeit der Ehe aus dogmatischer Sicht, „Theologische Quartalschrift”, 1995, nr 175, s. 125-135. 
jedyną drogą do Komunii Świętej jest rozgrzeszenie sakramentalne, które może być udzielone tylko tym, „którzy żałując, że naruszyli znak Przymierza i wierności Chrystusowi, są szczerze gotowi na taką formę życia, która nie stoi w sprzeczności z nierozerwalnością małżeństwa. Oznacza to konkretnie, że gdy mężczyzna i kobieta, którzy z ważnych powodów - jak na przykład wychowanie dzieci - nie mogą uczynić zadość zobowiązaniu separacji, postanawiają żyć w pełnej wstrzemięźliwości, czyli powstrzymać się od aktów,

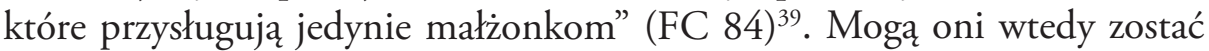
dopuszczeni do Komunii Świętej, przestrzegając jednak obowiązku uniknięcia zgorszenia. Kongregacja Doktryny Wiary już w liście o nierozerwalności małżeństwa z 11 kwietnia 1973 roku zaznaczyła, iż: „udzielając zgodę na dopuszczenie do sakramentów, Ordynariusze miejsca powinni z jednej strony czuwać nad przestrzeganiem obowiązującej w Kościele dyscypliny, a z drugiej zabiegać o to, by duszpasterze otaczali szczególną troską tych, którzy żyją w nieuregulowanych związkach, stosując w rozwiązywaniu tego rodzaju wypadków, oprócz innych odpowiednich środków, zatwierdzoną praktykę Kościoła dotyczącą zakresu wewnętrznego" ${ }^{\prime 0}$.

Problematyczna natomiast zdaje się sytuacja tych katolików, którzy rozwiedzieni, żyjąc w nowym związku, pozostają w błędnym przekonaniu o możliwości przystępowania do Komunii Świętej na skutek przyznania swojemu sumieniu, na podstawie własnego przekonania, ostatecznej decyzji o istnieniu bądź nieistnieniu poprzedniego małżeństwa i o ważności nowego związku. List Kongregacji Doktryny Wiary do Biskupów Kościoła Katolickiego na temat przyjmowania Komunii Świętej przez wiernych rozwiedzionych i żyjących w nowych związkach z 14 września 1994 roku $^{41}$

39 Congregatio pro Doctrina Fidei, Epistula Annus internationalis Familiae, dz. cyt., s. 974-979, nr 4; por. Sacra Paenitentiaria Apostolica, Decretum 18 IV 1936. Absolutio sacerdotum ab excommunicatione, ob attentatum etiam civile tantum matrimonium et actu cum muliere caste conviventium eorumąue admissio ud participationem sacramentorum more laicorum Sacrae Paenitentiariae Apostolicae exlusive reservatur, AAS, R. 28, 1936, s. $242-243$.

$4^{\circ}$ Congregatio pro Doctrina Fidei, Epistula Annus internationalis Familiae, dz. cyt., s. 974-979, nr 4; por. M. Zalba, Num in unione irregulari degentes, dz. cyt., s. 614-615.

${ }^{4}$ Congregatio pro Doctrina Fidei, Epistula Annus internationalis Familiae, dz. cyt., s. 974-979, nr 4; por. L. Scheffczyk, Ehe und Eucharistie. Grundsatze des Schreibens der Kongregation für die Glaubenslehre über den Kommunionempfang von wiederverheirateten ge- 
podkreśla, że przyznanie sobie takiej władzy jest niedopuszczalne, ponieważ nikt nie może być sędzią we własnej sprawie. Zgoda, dzięki której zaistniało małżeństwo, nie jest zwyczajną decyzją prywatną, lecz każdego z małżonków i ich małżeństwo stawia w specyficznej sytuacji kościelnej i społecznej, a sąd sumienia na temat własnej sytuacji małżeńskiej nie dotyczy tylko bezpośredniego stosunku między człowiekiem i Bogiem, tak żeby można w nim pominać pośrednictwo Kościoła. Nieuznawanie tego faktu oznacza w praktyce zaprzeczenie małżeństwu jako rzeczywistości kościelnej i sakramentalnej ${ }^{42}$.

Czy można zaakceptować wystarczalność subiektywnej pewności moralnej o nieważności zawartego małżeństwa? Skoro małżeństwo ma charakter publiczny, to nie można zgodzić się, by opinię o jego nieważności wydawała osoba prywatna, chociaż może zaistnieć sytuacja, w której dana osoba osiąga moralną pewność nieważności swojego małżeństwa, ale nie jest w stanie dowieść jej w trybie postępowania kanonicznego. Trudny problem stanowi sytuacja, w której domniemana przyczyna nieważności pozostaje ukryta, na skutek czego nie można jej dowieść na forum zewnętrznym. Należy podkreślić, iż w takich przypadkach dyscyplina Kościoła - od roku 1983 - proponuje nowe sposoby wykazywania nieważności poprzedniego związku, tak aby wykluczyć, jeśli to możliwe, wszelkie rozbieżności pomiędzy prawdą „sprawdzalną” w procesie (obiektywna) a prawdą subiektywną poznaną przez prawe sumienie. Jednoznacznie uznaje się wartość dowodową oświadczeń składanych przez same strony procesu, a więc przez małżonków ${ }^{43}$. Dopuszcza się, by takie oświadczenia miały wartość dowodową

schiedenen Gläubigen, „Forum Katholische Theologie”, 1995, nr 11, s. 133-136. Krytyczne uwagi do pisma Kongregacji Doktryny Wiary przedstawia m.in. A. Auer, Zur Seelsorge mit wiederverheirateten Geschiedenen, „Theologische Quartalschrift”, 1995, nr 175, s. 84-96.

${ }_{42}$ Congregatio pro Doctrina Fidei, Epistula Annus internationalis Familiae, dz. cyt., s. 974-979, nr 7, 8. Należy pamiętać, iż zgodnie z obowiązującym prawem kościelnym wiarą boską i katolicką należy wierzyć w to wszystko, co jest zawarte w słowie Bożym pisanym lub przekazanym, a wszyscy wierni mają obowiązek zachowywać konstytucje i dekrety wydane przez prawowitą władzę kościelną; zob. kan. 750-754; 212 \$ 1, 1364, 1371, 1 KPK 1983.

43 Kan. $1536 \$ 2$ KPK 1983: „W sprawach zaś dotyczących dobra publicznego przyznanie się sądowe i oświadczenia stron, które nie stanowią przyznania się, mogą mieć moc dowodową, którą winien ocenić sędzia, uwzględniając pozostałe okoliczności sprawy, ale nie może im przyznać mocy pełnego dowodu, chyba że dochodzą inne elementy, które je ostatecznie wzmacniają”. 
także w sprawach dotyczących nieważności małżeństwa ${ }^{44}$. Do momentu wejścia w życie Kodeksu prawa kanonicznego w 1983 roku przy ocenie dowodów w sprawach o orzeczenie nieważności małżeństwa obowiązywała zasada sformułowana w art. 117 instrukcji Provida Mater Ecclesia, w myśl której same zeznania małżonków nie stanowiły wystarczającego dowodu nieważności ich małżeństwa ${ }^{45}$. Zasada ta oparta była na negatywnej wizji człowieka, przyjmującej, że jest on zawsze skłonny kłamać dla własnej korzyści; choć zarazem znajdowała teoretyczne usprawiedliwienie w fundamentalnej zasadzie, leżącej u podstaw każdego procesu, wedle której nie każdy jest zdolny do złożenia świadectwa, które byłoby dowodem na jego korzyść ${ }^{46}$.

Zgodnie z tym, co wcześniej przedstawiono, do kompetencji ordynariuszy miejsc należało prawo wyrażania zgody na przystępowanie do sakramentów św. osób rozwiedzionych żyjących w ponownych związkach. Określali oni warunki, na jakich osoby decydujące się na dalsze pożycie w czystości mogły do nich przystępować. Wydaje się, iż utrzymanie obecnie kompetencji ordynariuszy w stosunku do tych osób zaostrza nieco normy obowiązującego prawa $^{47}$, gdyż ani adhortacja Familiaris consortio, ani też list Kongregacji

44 Kan. 1679 KPK 1983: „jeśli nie ma skądinąd pełnych dowodów, sędzia dla oceny zeznań stron według przepisu kan. 1536 powinien się posłużyć, jeśli to możliwe świadkami, co do prawdomówności samych stron, oprócz innych poszlak i wskazówek”.

45 Congregatio pro Disciplina Sacramentorum, Instructio servanda a Tribunalibus dioecesanis in pertractandis causis de nullitate matrimoniorum Provida Mater Ecclesia, 15 VIII 1936, art. 117, AAS, R. 28, 1936, s. 337: „Depositio iudicialis coniugum non est apta ad probationem contra valorem matrimonii constituendam".

${ }_{46}$ Zob. M. Pompedda, Kwestia dopuszczania do sakramentów osób rozwiedzionych, które powtórnie zawarly związek cywilny, „L'Osservatore Romano” (wyd. pol.), R. 14, 1993, nr 11, s. 54.

47 Na przykład Statuty Diecezji Drohiczyńskiej z 27 grudnia 1996 roku postanawiają, że: „Osoby żyjące w związku niesakramentalnym, które bardzo pragną przystępować do Komunii świętej, a jednocześnie zobowiązują się prowadzić życie czyste, należy za pośrednictwem proboszcza odesłać do ordynariusza. Ordynariusz dekretem ustali czas, miejsca i ewentualne dodatkowe warunki przystępowania tych osób do Stołu Pańskiego. Kopia dekretu ma być przesłana do wiadomości proboszcza. Także spowiednik, który stwierdza, że zachodzą powyższe okoliczności, może na prośbę penitenta udzielić rozgrzeszenia, a w uzasadnionej sytuacji może również zezwolić na przyjęcie Komunii świętej w środowisku, gdzie proszący jest nieznany. Jednocześnie winien zobowiązać proszącego, by o tym fakcie powiadomił własnego proboszcza” (I Synod Diecezji Drohiczyńskiej. Statuty. Dokumenty wykonawcze, red. A. Dzięga, M. Łaziuk, Drohiczyn 1997, nr 105, s. 95-96). 
Doktryny Wiary z 1994 roku nie stawia warunków co do wieku osób pragnących pozostawać we wstrzemięźliwości seksualnej, oraz utrzymania wyłącznej kompetencji ordynariuszy. Małżonkowie zobowiązani są jedynie do szczerej gotowości na taką formę życia, która nie pozostaje w sprzeczności z nierozerwalnością małżeństwa, a do otrzymania rozgrzeszenia w sakramencie pokuty wymagane jest takie usposobienie, które nakazuje odrzucenie popełnionego grzechu oraz postanowienie poprawy ${ }^{48}$, stąd należy mieć na uwadze również kan. 980, zgodnie z którym, jeśli nie ma wątpliwości co do dyspozycji penitenta, a ten prosi o rozgrzeszenie, spowiednik nie powinien go odmawiać ani odkładać.

Te same postanowienia prawne odnoszą się do katolików żyjących razem, bez żadnego związku, uznanej publicznie więzi czy tzw. małżeństw na próbę. Nie mogą oni przystępować do sakramentów św. Kościół bowiem ze względu na ostateczne, pierwotne i wypływające z wiary zasady nie może dopuścić do takiego rodzaju związków. Małżeństwo dwojga ochrzczonych jest realnym symbolem zjednoczenia Chrystusa z Kościołem, nie czasowego czy na próbę, ale wiernego na całą wieczność. Katolicy żyjący w rzeczywistych wolnych związkach zatracają religijny sens małżeństwa jako Przymierza Boga z Jego ludem i przez to wywołują poważne zgorszenie ${ }^{49}$.

Katolicy złączeni tylko ślubem cywilnym nie mogą zostać dopuszczeni do sakramentów, ponieważ ich sytuacja jest również nie do przyjęcia przez Kościół ${ }^{50}$. Do Komunii Świętej można ich dopuścić dopiero wówczas, gdy nawrócą się, zrywając z dotychczasowym trybem życia i przystąpią do sakramentu pojednania.

Według obowiązującej dyscypliny Kościoła tylko katolików żyjących w separacji i rozwiedzionych cywilnie, którzy nie zawarli nowego związku, zdając sobie sprawę z nierozerwalności ważnego węzła małżeńskiego, poświęcając

${ }^{48}$ Kan. 987 KPK.

49 Katechizm Kościoła Katolickiego podkreśla, iż pojęcie „wolny związek” odnosi się do sytuacji, takich jak: konkubinat, odmowa małżeństwa jako takiego, niezdolność do podjęcia trwałych i ostatecznych zobowiązań. Wszystkie te sytuacje znieważają godność małżeństwa, niszczą samo pojęcie rodziny, osłabiają znaczenie wierności. Są one sprzeczne z prawem moralnym. Akt płciowy powinien mieć miejsce wyłącznie w małżeństwie, poza nim stanowi zawsze grzech ciężki i wyklucza z komunii sakramentalnej; zob. KKK 2390; FC 80, 81.

\footnotetext{
so $\mathrm{FC} 82$.
} 
się jedynie spełnianiu swoich obowiązków rodzinnych i tych, które wynikają z wiary chrześcijańskiej, można dopuścić do Komunii Świętej i nie czynić im żadnych trudności w dopuszczaniu do sakramentów ${ }^{51}$.

To stanowisko Kościoła wynika z tego, że sakramenty św. nie są tylko środkami zbawczymi dla poszczególnych wiernych, ale przede wszystkim wyrażają jedność Kościoła w porządku obiektywnym jako wspólnoty sakramentalnej. Sakrament Eucharystii jest sakramentem jedności Kościoła, a Komunia sakramentalna z Chrystusem zawiera i zakłada przestrzeganie porządku komunii eklezjalnej. Nie może być ona prawdziwa i owocna - jak podkreśla to list Kongregacji Doktryny Wiary z 14 września 1994 roku jeśli wierny nie szanuje tego porządku ${ }^{52}$. Trudności stawiane osobom żyjącym w unio irregularis w dopuszczaniu do sakramentów św. mogłyby zostać zmienione, gdyby były normowane tylko przepisami pochodzenia kościelnego. Przepisy te jednak nie ustanawiają dyscypliny czysto kościelnej, ale odzwierciedlają wymogi prawa boskiego i potwierdzają pewną oraz niezmienną naukę Kościoła.

\section{Wierny należący do masonerii}

Normie kan. 915 Kodeksu prawa kanonicznego Jana Pawła II podlegają również członkowie stowarzyszeń masońskich, dlatego nie należy dopuszczać ich do Komunii Świętej. Kongregacja Doktryny Wiary w listopadzie 1983 roku opublikowała deklarację, w której potwierdza negatywny stosunek Kościoła do tej organizacji, chociaż Kodeks prawa kanonicznego, promulgowany w tym samym roku, o tego rodzaju stowarzyszeniach nie wspomina. Deklaracja ta głosi, że „wierni, którzy zapisują się do stowarzyszeń masońskich, znajdują się w grzechu ciężkim i nie mogą przystępować do Komunii Świętej" ${ }^{\prime 3}$, ponieważ - jak podkreśla dalej - zasady tego rodzaju stowarzyszeń

sI $\quad$ FC 83.

52 Congregatio pro Doctrina Fidei, Epistula Annus internationalis Familiae, dz. cyt., s. 974-979, nr 9.

53 Congregatio pro Doctrina Fidei, Declaratio de associationibus masonicis, 26 XI 1983, AAS, R. 76, 1984, 300; tekst polski w: W trosce o petnię wiary, dz. cyt., s. 209. Na temat stowarzyszeń masońskich istnieje bardzo bogata literatura. Zagadnienie to szeroko opracował m.in. A. Zwoliński, Wokót masonerii, Kraków 1995; zob. także S. Krajski, Masoneria polska 1993, Warszawa 1993; tenże, Masoneria polska i okolice, Warszawa 1997. 
są nie do pogodzenia z nauką Kościoła i dlatego przynależność do nich została zakazana. Na wątpliwości, jakie pojawiły się po promulgacji kodeksu, Kongregacja odpowiedziała, że brak wyraźnej wzmianki o stowarzyszeniach masońskich wynika z przyjętego kryterium redakcyjnego kodeksu, które zachowano także co do innych stowarzyszeń, tak samo pominiętych w kodeksie milczeniem. Kongregacja zwróciła również uwagę na fakt, iż lokalne władze kościelne nie mają prawa osądu natury stowarzyszeń masońskich, który implikowałby uchylenie tego, co wyżej ustalono i co zostało zawarte w deklaracji z 17 lutego 1981 roku $^{54}$. Jeżeli więc wiadomo, że ktoś bez wątpienia jest członkiem takiego stowarzyszenia, zgodnie z deklaracją znajduje się w grzechu ciężkim jawnym, to nie należy dopuszczać go do Komunii Świętej. Pewne wątpliwości budzi natomiast sytuacja, w której wierny należy do stowarzyszenia masońskiego niedziałającego przeciwko Kościołowi ${ }^{55}$. Kodeks prawa kanonicznego z 1917 roku zabraniał wprost katolikom przynależności do stowarzyszeń masońskich i im podobnych pod karą ekskomuniki zarezerwowanej Stolicy Apostolskiej w sposób zwyczajny ${ }^{56}$. Jednak z odpowiedzi Kongregacji Doktryny Wiary opublikowanej w 1974 roku wynikało, iż mogą istnieć stowarzyszenia masońskie, które nie działają przeciwko Kościołowi ${ }^{57}$, ale w 1981 roku Kongregacja ta podkreśliła jednoznacznie, iż lokalnym władzom kościelnym nie wolno wydawać publicznych osądów co do natury jakiegoś stowarzyszenia masońskiego i utrzymuje w mocy dotychczasową dyscyplinę kanoniczną w tej materii.

Zgodnie z obowiązującym od 1983 roku prawem przynależność wiernego do stowarzyszeń masońskich, na mocy kan. 915, zabrania mu przystępowania do Komunii Świętej dopóki pozostaje w tym stowarzyszeniu.

${ }_{54}$ Sacra Congregatio pro Doctrina Fidei, Declaratio de canonica disciplina quae sub poena excommunicationis vetat ne catholici nomen dent sectae Massonicae aliisque eiusdem generis associationibus, 17 II 1981, AAS, R. 73, 1981, s. 240-241; tekst polski w: W trosce o petnię wiary, dz. cyt., s. 174-175.

ss Kan. 1374 KPK 1983: „Kto zapisuje się do stowarzyszenia działającego w jakikolwiek sposób przeciw Kościołowi, powinien być ukarany sprawiedliwą karą; kto zaś popiera tego rodzaju stowarzyszenia lub nim kieruje, powinien być ukarany interdyktem”.

s6 Kan. 2335 KPK 1917: „Nomen dantes sectae massonicae aliisve eiusdem generis associationibus quae contra Ecclesiam vel legitimas civiles potestates machinantur, contrahunt ipso facto excommunicationem Sedi Apostolicae simpliciter reservatam”.

57 Notificatio diei 18 Julii 1974, [w:] Wtrosce o petnię wiary, dz. cyt., s. 174. 


\section{Wierny należący do partii komunistycznych}

W roku 1949 Kongregacja Świętego Oficjum ustosunkowała się do wiernych zapisujących się do partii komunistycznych, gdyż zwrócono się do niej z trzema pytaniami:

- Czy wolno zapisywać się do partii komunistycznej lub sprzyjać tej partii?

- Czy wolno drukować, rozpowszechniać lub czytać książki, czasopisma, dzienniki, ulotki, które popierają naukę lub działalność komunistów, lub też posyłać swoje opracowania do druków w tych pismach?

- Czy wolno dopuszczać do Komunii Świętej wiernych, o których mowa w pytaniu 1 i 2, którzy świadomie i dobrowolnie w ten sposób postępują?

Odpowiedź na wszystkie trzy pytania była negatywna, wyjaśniając, iż komunizm opiera się na przesłankach materialistycznych i jest przeciwny wierze chrześcijańskiej ${ }^{58}$. Wiernych tych nie można dopuszczać do sakramentów, jak długo trwają w stanie grzechu ciężkiego. Z odpowiedzi tej wynika, iż wiernych należy niekiedy dopuścić do Komunii Świętej, jeśli zapisali się do partii nieświadomie lub pod przymusem. W pewnych przypadkach bowiem może istnieć wpis czysto materialny, np. kiedy do zapisania się do partii komunistycznej zmuszani byli robotnicy czy inne osoby, które chciały utrzymać swój status zawodowy ${ }^{59}$. Jeżeli nie jest pewne, że przynależność do partii jest formalna (świadoma, w sposób wolny), wówczas wiernego należy dopuścić do Komunii Świętej ${ }^{60}$. Kongregacja Świętego Oficjum 11 sierpnia 1949 roku wydała również deklarację, na mocy której nie wykluczyła celebrowania

s8 Congregatio S. Officii, Decretum Quaesitum est, 1 VII 1949, AAS, R. 41, 1949, s. 334; zob. Pius PP. XI, Litterae encyclicae Divini Redemptoris, AAS, R. 29, 1937, s. 65-106.

59 Na przykład Pastuszko pisze, iż stosowanie dekretu Kongregacji w Polsce było utrudnione, ponieważ „komunizm w naszym kraju opierał się na kłamstwie i zniewalaniu, a poszczególni członkowie partii komunistycznych, a także sprzyjający tym partiom właściwie nie wiedzieli, co czynią i nie byli wolni w postępowaniu” (M. Pastuszko, Najświętsza Eucharystia wedtug Kodeksu Prawa Kanonicznego Jana Pawła II, Kielce 1997, s. 153).

6o J. Hendriks, Adsacram communionem, dz. cyt., s. 175. Warto przypomnieć, iż wpis materialny następuje wówczas, gdy chodzi o przynależność bierną, która następuje z przyczyny proporcjonalnie poważnej i nie jest aktem wewnętrznie złym. Jeżeli natomiast przynależność formalna jakiegoś wiernego do partii komunistycznej nie jest notoryczna, to kapłan może udzielić mu Komunii Świętej, jeśli publicznie o nią prosi; zob. P. Palazzini, Communismus, [w:] Dictionarum morale et canonicum, red. tenże, t. 1-4, Roma 1962-1968, s. 797. 
małżeństwa komunistów, „zważywszy na szczególną naturę sakramentu małżeństwa" ${ }^{\prime 1}$.

\section{Obłożeni ekskomuniką i interdyktem}

Ekskomunikowanemu lub podlegającemu interdyktowi po wymierzeniu lub deklaracji kary nie zezwala się na przyjęcie Komunii Świętej zgodnie z kan. 915 oraz kan. $1331 \$ 1$ nr 2, a także kan. 1332 KPK $^{62}$. Kary ferendae sententiae nie są wymierzane, jeśli „zewnętrzne naruszenie ustawy lub nakazu nie jest ciężko poczytalne na skutek winy umyślnej lub nieumyślnej”"63. Przy zaistnieniu więc tych sankcji wierny nie powinien zostać dopuszczony do Komunii Świętej. Sytuację wyjątkową stanowi tu oczywiście niebezpieczeństwo śmierci wiernego ${ }^{64}$. Zgodnie z kan. $1352 \$ 1$ zakaz przyjmowania sakramentów lub sakramentaliów ulega zawieszeniu tak długo, jak długo winny znajduje się w niebezpieczeństwie śmierci ${ }^{65}$. Natomiast kary latae sententiae

6r Congregatio S. Officii, Declaratio de communistarum matrimonii celebratione, 11 VIII 1949, AAS, R. 41, 1949, s. 427-428, zgodnie z którą, zważywszy na szczególną naturę sakramentu małżeństwa, którego szafarzami są sami kontrahenci, a kapłan pełni funkcję świadka z urzędu, kapłan może asystować przy małżeństwach komunistów na mocy kan. 1065, 1066 KPK.

${ }^{62}$ Kan. $1331 \$ 1$, nr 2: „Ekskomunikowanemu zabrania się: [...] sprawować sakramenty i sakramentalia oraz przyjmować sakramenty”; kan. 1332: „Ukarany interdyktem jest związany zakazami, o których mowa w kan. $1331 \$ 1$, nr 1 (zabrania się jakiegokolwiek udziału w posługiwaniu, w sprawowaniu ofiary eucharystycznej lub w jakichkolwiek innych obrzędach kultu)” i nr 2: ,jeśli zaś interdykt został wymierzony lub deklarowany, należy zastosować przepis kan. 1331 \$ 2 nr 1 (Jeśli ekskomunika została wymierzona lub deklarowana, przestępca gdyby chciał działać wbrew postanowieniu $\$ 1$, nr 1 , powinien być usunięty albo czynność liturgiczna przerwana, chyba że przeszkadza temu poważna racja)”. Szerzej na temat ekskomuniki i interdyktu zob. M. A. Myrcha, Ekskomunika, Warszawa 1959; tenże, Interdykt, Warszawa 1960; J. Krukowski, F. Lempa,Sankcje w Kościele, [w:] Komentarz do Kodeksu Prawa Kanonicznego z 1983 r., red. W. Wójcik, J. Krukowski, F. Lempa, t. 4, Lublin 1987, s. 163-170.

${ }_{6}$ Kan. $1321 \$ 1$ KPK 1983.

${ }^{64}$ M. Pastuszko, Sakrament pokuty i pojednania, Kielce 1999, s. 329; por. J. Syryjczyk, Sankcje w Kościele. Część ogólna, Warszawa 2008, s. 286-287.

65 Por. też kan. 1335: „Jeżeli cenzura zabrania sprawowania sakramentów lub sakramentaliów albo podejmowania aktów rządzenia, zakaz zostaje zawieszony, ilekroć jest to konieczne do udzielenia posługi wiernym znajdującym się w niebezpieczeństwie śmierci”. 
są wymierzane z chwilą dokonania przestępstwa, zarówno przestępstwa publicznego, jak i tajnego. Skutkiem tejże karty jest obowiązek jej zachowania w obu zakresach, tzn. w zakresie zewnętrznym, jak i wewnętrznym. Z uwagi na fakt, że wymierzona kara jest częścią ustawy, przestępca winien ją uznać za słuszną we własnym sumieniu oraz ma prawny i moralny obowiązek przyjęcia kary i jej przestrzegania ${ }^{66}$. Wymóg podporządkowania się karze, dopóki nie jest deklarowana, nie jest bezwzględny ${ }^{67}$. Cenzura latae sententiae, która nie została deklarowana ani też nie jest notoryczna w miejscu przebywania przestępcy, o tyle zostaje zawieszona w całości lub w części, o ile wierny nie może jej zachować bez niebezpieczeństwa poważnego zgorszenia lub zniesławienia ${ }^{68}$. W przypadku cenzury kościelnej latae sententiae niedeklarowanej, niebezpieczeństwo poważnego zgorszenia lub zniesławienia uważane jest za ważny powód, który zawiesza obowiązek przestrzegania kary, chyba że kara jest notoryczna w miejscu, gdzie przebywa przestępca ${ }^{69}$. Jeśli kara zostaje wymierzona lub deklarowana przez władzę kościelną, zakaz uczestnictwa w Eucharystii obowiązuje także na forum zewnętrznym i zakazuje się, by ekskomunikowany i podlegający interdyktowi dopuszczany był do Komunii Świętej ${ }^{70}$.

\section{Podsumowanie}

Zagadnienie dotyczące dopuszczania wiernych katolików do Komunii Świętej stanowiło zawsze trudny problem w historii Kościoła. Stanowisko Urzędu Nauczycielskiego Kościoła, wyrażone w kan. 915 KPK, wydaje się surowe, lecz uzasadnione niezmienną jego nauką. Katolicy ekskomunikowani lub podlegający interdyktowi, po wymierzeniu bądź deklaracji kary, jak również inne osoby trwające $\mathrm{z}$ uporem $\mathrm{w}$ jawnym grzechu ciężkim powinni mieć zawsze świadomość tego, że nie Kościół ogranicza ich w uprawnieniach, jakie im przysługują, ale to oni sami pozbawiają się tego prawa. Nie jest

\footnotetext{
66 P. Kurczyński, De natura et observantiapoenarum latae sententiae, Lublin 1938, s. 56-57.

${ }^{67}$ J. Syryjczyk, Sankcje w Kościele. Czesść ogólna, dz. cyt., s. 73.

68 Zob. kan. $1352 \$ 2$.

69 J. Krukowski, Sankcje w Kościele, dz. cyt., s. 190.

70 J. Syryjczyk, Sankcje w Kościele. Część ogólna, dz. cyt., s. 284-285.
} 
to nauka nowa czy zaostrzenie dyscypliny kościelnej. Jest to kontynuacja nauczania Jezusa Chrystusa.

\title{
Restricting the Believer's Right to Holy Communion - Canon 915 CIC 1983
}

\begin{abstract}
Summary
The issue of admitting catholic believers to Holy Communion has always been a difficult one in the history. The position of the Church as expressed in Canon 915 of Code of Canon Law 1983 seems strict, but justified with its invariable teachings. The Catholics who have been excommunicated or interdicted after the imposition or declaration of the penalty and others obstinately persevering in manifest grave sin should always be aware of the fact, that it is not the Church that restricts them in their entitlements, but it is them that deprive themselves of that right. This is not a new teaching or tightening of ecclesiastical discipline. This is a continuation of Jesus's teaching.
\end{abstract}

Keywords: Holy Communion, can. 915, Code of Canon Law 1983, sacraments 
